\title{
都市屋外および半屋外空間における短波長分光放射環境の実測
}

\section{FIELD MEASUREMENT OF SPECTRAL ENVIRONMENT IN URBAN OUTDOOR AND SEMI-OUTDOOR SPACE}

\author{
一八瀬 雅之*, 石野久彌**, 郡 公子***, 永田明 寛**** \\ Masayuki ICHINOSE, Hisaya ISHINO, Kimiko KOHRI \\ and Akihiro NAGATA
}

\begin{abstract}
This paper presents actual condition of spectral environment in urban outdoor space as represented by canopy space surrounded by building walls, and in urban semi-outdoor space as represented by glass-enclosed atrium. Measurement surveys are made with spectroradiometer which can measure 350-2500nm spectrum continuously, and with electric camera platform which can scan over the sky. Measurement result is that near-infrared region figure in canopy space, ultraviolet-visible region figure in atrium contrastively. Especially, in Oasis 21 covered glazed roof with water pond, solar radiation of near-infrared region is reduced drastically by spectral selectivity of water.
\end{abstract}

\section{Keywords: Spectral environment, Field measurement, Canopy space, Atrium, Waveband selectivity, Ultraviolet-visible region, Near infrared region \\ 分光放射環境，実測，都市キャノピー，アトリウム，波長選択性，紫外可視光域，近赤外域}

\section{1 はじめに}

ヒートアイランド問題の顕在化に伴い，都市の熱環境も重要 視される傾向にある. 都市屋外空間として代表される都市キャ ノピー空間は多種多様なビル外壁面に囲まれており，照り返し や多重反射によってこれらの表面を介して居住域に到達する日 射は熱環境に大きな影響を及ぼしている，また一方で，ガラス を多用することで空間の透明性を高め, 直達日射の透過も許容 するような半屋外的な空間も都市における特徵的なものである.

屋外・半屋外空間においては日射を考慮した熱環境の評価が 不可欠であり，このような観点からの研究は数多く行われてい る. シミュレーションと実際の温冷感を比較した事例としては, 鄭ら ${ }^{1)}$ による温冷感・平均皮膚温と長波・短波を考慮した作用 温度との相関性の検討などがある，放射環境の詳細な実測の事 例としては, 足永 ${ }^{2)} に よ る$ 全球 338 点のトラバース計測を用い た屋外における地物単位での長波・短波放射熱流束の特性を検 討した事例や, 浅野ら ${ }^{3)}$ による屋外空間における 3 次元熱画像 作成による MRT 分布評価，郡ら ${ }^{4)}$ による赤外線放射カメラと 魚眼写真によるアトリウム放射環境の簡易実測評価などがある.

既往の研究の多くは，放射を日射領域の短波長と低温放射の 長波長の波長帯で評価しているが，成田ら ${ }^{5)}$ は日射の波長帯が 人体の感覚量に影響することを被験者実験によって示しており， 屋外・半屋外空間において絶対量の多い日射について, 波長特 性の考慮が必要であることが示唆されている．また，筆者ら ${ }^{6)}$
は，ガラスや建材サンプルの分光透過・反射率データの代表的 な日射の分光分布に対する日射物性値の感度解析結果から，短 波長域の単一波長帯指標に起因する波長積分値の誤差が少なか らずあることを示し，建材の日射物性值を 780nm で紫外可視 光域と近赤外域の 2 波長帯に区分して扱う手法を提案し，日射 と建材の分光特性を良く反映できることを示した.

本論文は, 既報 ${ }^{6)}$ の延長線上として, 都市屋外・半屋外にお ける実測調査によって，ビル外壁面や舗装地面を経由する照り 返し日射や，ガラス面を透過する日射，植栽や水などの自然地 物を透過・反射する日射の波長特性の実態を明らかにしようと するものである.

\section{2 実測概要}

\section{1 実測対象および期間}

表 1 に測定日時および場所の一覧を示す．2003 年から 2004 年にかけて, 東京丸の内を中心に新宿, お台場, 汐留, 六本木, 横浜, 川崎, 南大沢の各地において, 建物群による屋外キャ) ピー空間やアトリウムなどガラスを多用した半屋外空間を対象 に測定を行った，天候状態は快晴または雲が厚い量天日を狙っ て測定を行った. また, 表 1 とは別に, 水盤ガラス屋根を有す る名古屋市栄のオアシス 21 において, 2003 年度に夏季, 秋季, 冬季を通して実測を行った.
* 東京都立大学大学院工学研究科 博士課程 - 修士 (工学)

** 東京都立大学大学院工学研究科 教授.工博

*** 宇都宮大学大学院工学研究科 助教授・工博

**** 東京都立大学大学院工学研究科 . 助教授・博士 (工学)
Graduate Student, Graduate School of Eng. Tokyo Metropolitan Univ, M. Eng. Prof., Graduate School of Eng., Tokyo Metropolitan Univ., Dr. Eng.

Assoc. Prof., Graduate School of Eng., Utsunomiya Univ., Dr. Eng.

Assoc. Prof., Graduate School of Eng., Tokyo Metropolitan Univ., Dr. Eng. 


\section{表 1 測定日時・場所の一覧}

\begin{tabular}{|c|c|c|c|c|}
\hline 年月日 & 時刻 & 場所 & 件数 & 測定丙容 \\
\hline $2003 / 1 / 9$ & $10: 50-14: 50$ & 齊の内 & 89 & 分光反射率 \\
\hline $2003 / 1 / 10$ & $10: 00-15: 40$ & 丸の内 & 141 & 分光反射率 \\
\hline $2003 / 1 / 12$ & $10: 30-14: 10$ & 新宿 & 71 & 分光反射率 \\
\hline $2003 / 1 / 13$ & $11: 10-15: 00$ & 南大沢 & 91 & 分光反射率 \\
\hline $2003 / 5 / 22$ & $10: 30-14: 10$ & 丸の内 & 8 & 分光放射輝度分布 \\
\hline $2004 / 8 / 13$ & $11: 20-16: 10$ & 丸の内 & 4 & 分光放射輝度分布 \\
\hline $2004 / 9 / 16$ & $11: 50-12: 10$ & 丸の内 & 4 & 分光放射耀度分布 \\
\hline $2004 / 9 / 22$ & $10: 10-14: 10$ & 丸の内 & 19 & 分光放射量 \\
\hline $2004 / 10 / 6$ & $9: 50-15: 20$ & 丸の内, お台場 & 14 & 分光放射星 \\
\hline $2004 / 10 / 7$ & $9: 00-15: 20$ & 新宿, 汐留, 六本木 & 19 & 分光放射量 \\
\hline $2004 / 10 / 15$ & $10: 10-15: 10$ & 没, 川䗁 & 8 & 分光放射量 \\
\hline
\end{tabular}

\section{2 測定項目および使用計器}

表 2 に実測に使用した計器の一覧を示す. 分光放射計は 350$2500 \mathrm{~nm}$ まで一括して連続的なスペクトルを計測できるもので あり, 光の導入開口角を $1^{\circ}, 25^{\circ}, 180^{\circ}$ に変更し, 分光放射輝 度および分光放射量を測定した. 電動雲台は分光放射計アタッチ メント形状に合わせてメーカーに特注製作したものである. 分 光放射計と電動雲台で構成したシステムで全天の分光放射輝度 分布を測定した. また, 魚眼写真を撮影して形態係数の算出や 放射輝度分布測定点の同定に用いた.

表 2 使用計器一筧

\begin{tabular}{|c|c|}
\hline 計器名 & メーカー・型番 \\
\hline \hline 分光放射計 $(350-2500 \mathrm{~nm})$ & Analytical Spectral Devices, Inc. \\
\hline 電動雲台・三脚 & 甲南エレクトロニクス \\
\hline デジタルカメラ & Nikon CoolPix950 \\
\hline 魚眼レンズ & Nikon FC-E8 \\
\hline
\end{tabular}

\section{3 分光放射輝度分布計測システム}

図 1 に分光放射輝度分布計測システムの外観を示す，電動雲 台に分光放射計（開口角 $1^{\circ}$ ）を取り付け，任意の走査スケジュー ルをパソコン上から制御することが可能である. 全天の走査位 置および点数は, 走查時間（本システムは約 4 分）との兼ね合い から CIE の IDMPによるガイドに準拠した全天 145 点とした.



図 1 分光放射輝度分布計測システム

\section{4 リファレンスとしての日射量}

測定時の基準日射量として, 測定の合間に障害物のない開け た場所で全天分光日射量を測定した. 直達・天空成分の分離計 測は現場では困難なので, 測定日時の太陽高度, 大気圧, 可降 水量 (気温・湿度から推定 ${ }^{7)}$ ) を用いて $\mathrm{Bird}^{8)}$ の分光日射モデ ルによって算出した全天日射量との整合性を確認し, 直達・天 空日射の分光分布をリファレンスに用いた.

\section{3 都市キャノピー空間の分光放射環境}

\section{1 建物外表面および路面の分光反射特性}

(1) 測定および算出方法

屋外表面のアルベド調査はリモートセンシングのような大き


によるファサード調査や，吉田ら ${ }^{10)}$ による積分球を用いた路 面の分光反射率測定などがあるが，本研究では路面だけでなく 鈶直面を含めて数多くの測定対象の波長特性を得ることに主眼 を㯰き，式 (1) で示す白色標準板 Spectralon ${ }^{(\mathrm{TM})}$ を基準とし た垂直反射率を測定した

$$
\rho_{(\lambda)}=R D_{(\lambda)} / R D_{W h(\lambda)}
$$

$$
\begin{aligned}
& \rho_{(\lambda)} \quad: \text { 分光反射率 }[-] \\
& R D_{(\lambda)}: \text { 測定対象面の放射輝度 }\left[\mathrm{W} /\left(\mathrm{m}^{2} \cdot \mathrm{sr} \cdot \mathrm{nm}\right)\right] \\
& R D_{W h(\lambda)} \text { : 白色標準板の放射輝度 }\left[\mathrm{W} /\left(\mathrm{m}^{2} \cdot \mathrm{sr} \cdot \mathrm{nm}\right)\right]
\end{aligned}
$$

測定した分光反射率を基準太陽光の分光分布で波長積分して， 日射反射率を式 (2) で算出した. なお，紫外可視光域と近赤外 域各波長帯の日射反射率 $\rho_{\mathrm{UV}+\mathrm{V}}$ おひび $\rho_{\mathrm{NIR}}$ は，積分波長域を 350-780nm, 780-2500nm としてそれぞれ求めた.

$$
\begin{aligned}
& \rho=\int \rho_{(\lambda)} \cdot I_{(\lambda)}^{S T D} d \lambda / \int I_{(\lambda)}^{S T D} d \lambda \\
& \rho \quad: \text { 日射反射率 }[-] \\
& I_{(\lambda)}^{S T D}: \text { 基準太陽光の分光分布 }\left[\mathrm{W} /\left(\mathrm{m}^{2} \cdot \mathrm{nm}\right)\right]
\end{aligned}
$$

(2) 測定結果

図 2 に，測定した分光反射率の測定結果の一例を示す.タイ ルや石材などは既報 ${ }^{6)}$ と同様に近赤外域の反射率が大きくなる 傾向が強い，金属パネル面はスペクトル形状に固体差が大きい が，近赤外域の反射率が大きい傾向であった．

図 3 は, 多数測定した壁面や路面などの日射反射率の波長特 性を, 紫外可視光域と近赤外域で比較したものである. 全般的 に見て近赤外域の反射率の方が大きいという結果であった.

\section{2 分光放射旦の波長帯特性}

（1）壁面反射日射の基準化評価

キャノピー下部における分光放射量 $\mathrm{I}_{\mathrm{TH} \text { canopy ( }(\lambda)}$ のうち, 壁 面を反射して到達した分光放射量 $\mathrm{I}_{\mathrm{Rcanopy}(\lambda)}$ を式 (3) で求めた.

$$
I_{R c a n o p y(\lambda)}=I_{T H c a n o p y(\lambda)}-F_{S K Y} \cdot I_{S H(\lambda)}
$$

$I_{\text {Rcanopy (ג) }}$ 壁面・地物を経由してキャノピー下部に到達 する分光放射量 $\left[\mathrm{W} /\left(\mathrm{m}^{2} \cdot \mathrm{nm}\right)\right]$

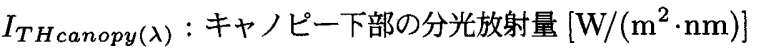

$I_{S H(\lambda)}$ : 水平面天空分光日射量 $\left[\mathrm{W} /\left(\mathrm{m}^{2} \cdot \mathrm{nm}\right)\right]$

$F_{S K Y}:$ キャノピー下部における天空率 [-]

また，全天日射量に対するキャノピー壁面を経由して下部居 住域に到達する日射の比率を, キャノピー空間の分光反射指標

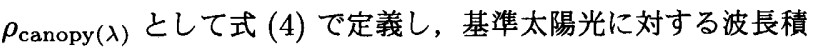




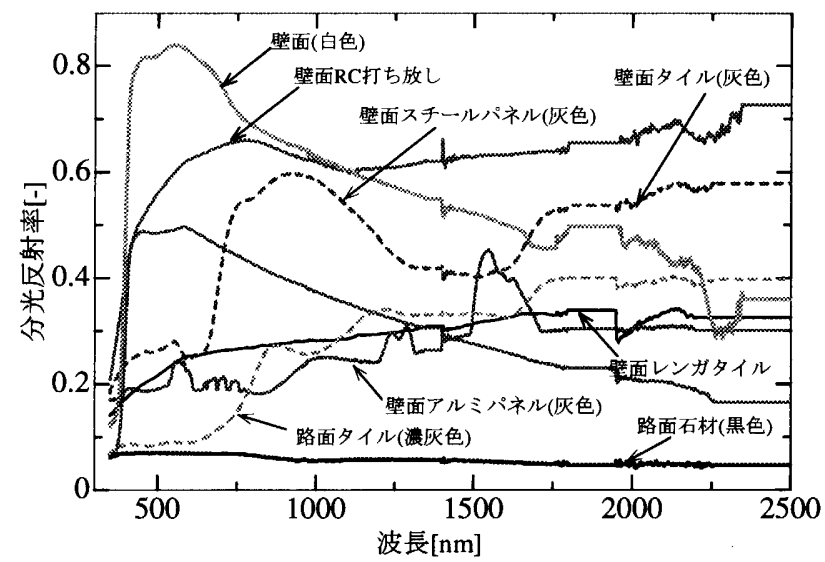

図 2 外壁面・路面の分光反射率



図 3 外壁面・路面の日射反射率の波長帯比較（392 件）

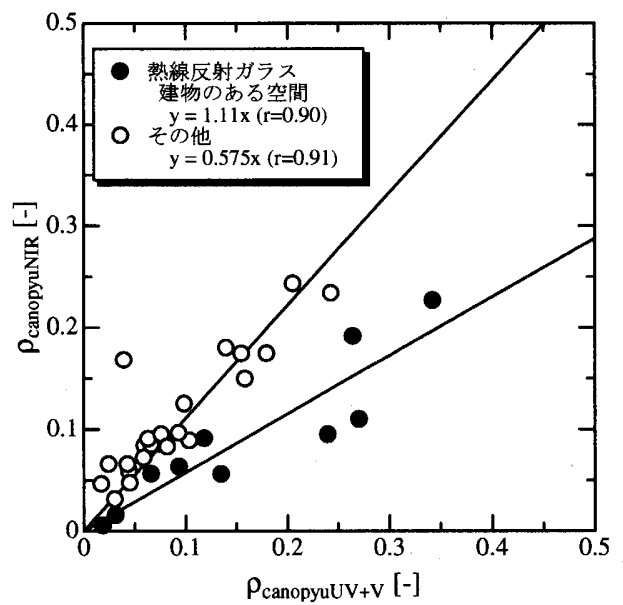

図 4 キャノピー空間日射反射指標の波長帯比較 (33 地点データ)

分值 $\rho_{\text {canopy }}$ を式 (5) で求めた.

$$
\begin{aligned}
& \rho_{\text {canopy }(\lambda)}=I_{R \text { canopy }(\lambda)} / I_{T H(\lambda)} \\
& \rho_{\text {canopy }}=\int \rho_{\text {canopy }(\lambda)} \cdot I_{(\lambda)}^{S T D} d \lambda / \int I_{(\lambda)}^{S T D} d \lambda \\
& \rho_{\text {canopy }(\lambda)}: \text { キャノピー空間の分光反射指標 }[-] \\
& I_{T H(\lambda)}: \text { 全天分光日射量 }\left[\mathrm{W} /\left(\mathrm{m}^{2} \cdot \mathrm{nm}\right)\right] \\
& \rho_{\text {canopy }}: \text { キャノピー空間の日射反射指標 }[-]
\end{aligned}
$$

\section{(2) 測定結果}

図 4 は晴天時の 33 地点におけるキャノピー空間日射反射指 標 $\rho_{\text {canopy }} 2$ 波長帯で比較したものである. 熱線反射ガラス 壁面から鏡面反射の日射がキャノピ一下部に到達していた場合 と，その他を区別して示している．熱線反射ガラス壁面のある 空間では紫外可視光域の反射が卓越し，その他では近赤外域が 若干卓越するという結果になった。波長選択性のあるガラス壁 面による影響が明確に現れる結果となった。

\section{3 分光放射輝度の波長帯特性および空間分布特性}

\section{（1）分光放射輝度の基準化指標}

式 (6)によって，キャノピー空間の分光放射輝度分布を測定 時の水平面全天日射量で基準化した $\kappa(\lambda)$ を，キャノピーを構成 する各面からの放射輝度の波長特性を表す指標として定義した. この基準化した分光放射輝度を，反射率と同様に式 (7) で示す ように基準太陽光で波長積分して基準化放射輝度 $\kappa$ を求めた。

$$
\begin{aligned}
& \kappa_{(\lambda)}= R D_{(\lambda)} / I_{T H(\lambda)} \\
& \kappa= \int \kappa_{(\lambda)} \cdot I_{(\lambda)}^{S T D} d \lambda / \int I_{(\lambda)}^{S T D} d \lambda \\
& \kappa_{(\lambda)} \quad: \text { 基準化分光放射輝度 }[1 / \mathrm{sr}] \\
& \kappa \quad: \text { 基準化放射輝度 }[1 / \mathrm{sr}]
\end{aligned} .
$$

（2）基準化放射輝度の波長帯比率

図 5 に基準化放射輝度の波長帯比率 $\kappa_{\mathrm{NIR}} / \kappa_{\mathrm{UV}}+\mathrm{V}$ の空間分 布を示す．建物外壁面では波長帯比率が 1 以上で分布し，近赤 外が卓越していることが明確である. 特に, 図中央のビルは低放 射ガラスの外壁で大きなピークが見られる．また，樹葉特有の 波長選択性により樹木付近で比率が 3 程度と大きくなっている.



図 5 都市キャノピー空間における基準化放射輝度の波長帯比率 $\kappa_{\mathrm{NIR}} / \kappa_{\mathrm{UV}+\mathrm{V}}$ の空間分布 2004.8/13 14:58 (暴天)

\section{(3) 地物別の波長帯特性}

図 6 は, 複数の地点で行った分光放射輝度分布測定デー夕を, 魚眼写真上の位置および分光特性から地物別にソートし，代表 的な地物として樹木, 壁面, ガラス面（低放射）, ガラス面（そ の他）にまとめて基準化放射輝度の波長帯特性を示したもので ある. 図 6(a) は㟟天時のデー夕, 図 6(b) は晴天時のデータで 
ある．分類ごとに，波長帯特性を表す $\kappa_{\mathrm{NIR}} / \kappa_{\mathrm{UV}+\mathrm{V}}$ が明確に 表れていることがわかる．最も波長選択性が大きいのは樹木で あった．壁面や低放射ガラス面も近赤外域が卓越している。 そ の他のガラス面は紫外可視光域が卓越している. 䰹天時に対し て晴天時は指向反射の影響があるために，壁面とガラス面にお いて相関性が悪くなるが，全体的な傾向は同様であり，全天日 射を基準とした指標による空間の波長特性評価は妥当といえる.

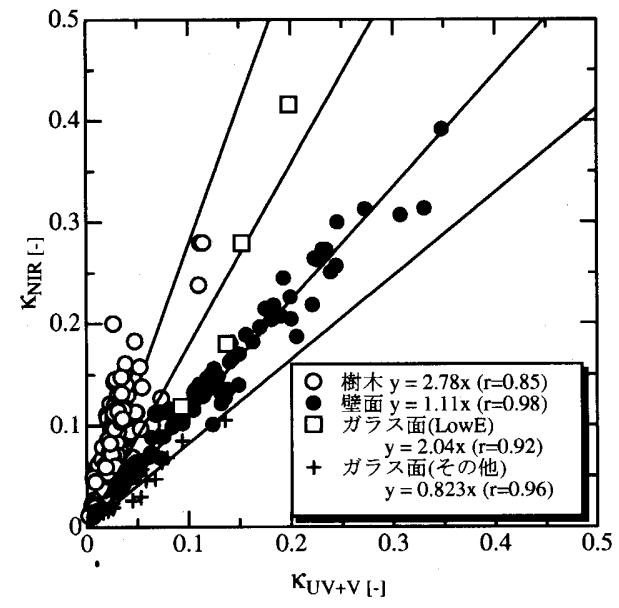

(a) 暈天時 (4 地点データ)

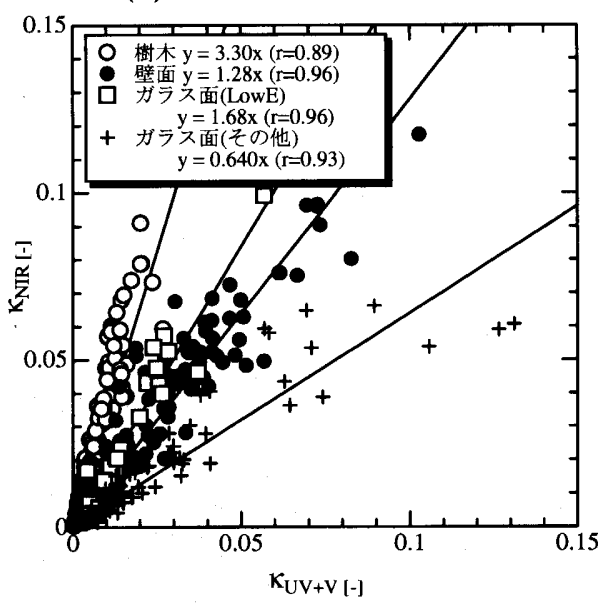

(b) 晴天時 (15 地点データ)

図 6 地物別の基準化放射輝度 $\kappa$ の波長帯比較

\section{4 都市半屋外空間の分光放射環境}

\section{1 アトリウムにおける分光放射量}

（1）透過日射の基準化評価

キャノピーにおける反射日射の基準化と同棣に，アトリウム下 部の日射量の全天日射量に対する比率を, アトリウムの分光透過 指標として式 (8) で求めた. 基準太陽光に対する積分值 $\tau_{\text {atrium }}$ および, 波長帯の積分値についても, 式 (8) で同様に算出した.

$$
\begin{aligned}
\tau_{\text {atrium }(\lambda)} & =I_{T H \text { atrium }(\lambda)} / I_{T H(\lambda)} \\
\tau_{\text {atrium }} & =\int \tau_{\text {atrium }(\lambda)} \cdot I_{(\lambda)}^{S T D} d \lambda / \int I_{(\lambda)}^{S T D} d \lambda \\
\tau_{\text {atrium }(\lambda)} & : \text { アトリウムの分光透過率指標 }[-]
\end{aligned}
$$

$$
I_{\text {THatrium(ג) }} \text { : アトリウム下部の分光放射量 }\left[\mathrm{W} /\left(\mathrm{m}^{2} \cdot \mathrm{nm}\right)\right]
$$

(2) 測定結果

図 7 は 42 件のアトリウムにおける日射透過指標を，2 波長 帯で比較したものである. キャノピー空間においては近赤外域 が卓越していたのとは対照的に，ガラスが有する紫外可視光域 における高い波長選択透過性を反映した傾向が明確である.

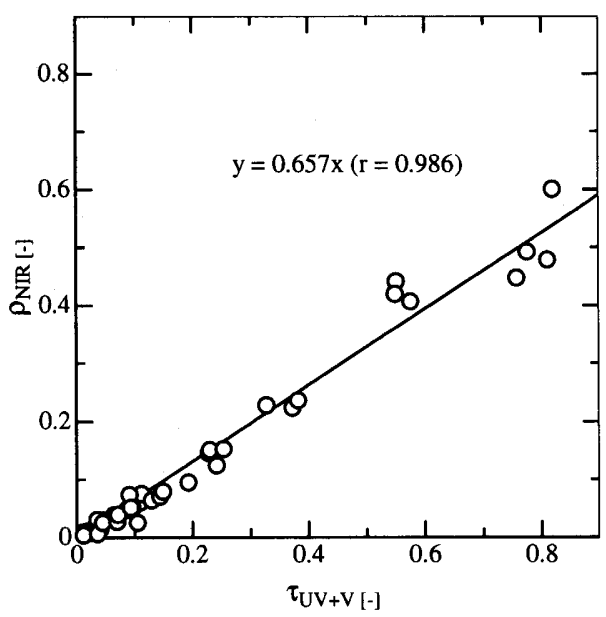

図 7 アトリゥム日射透過率の波長带比較（42 件）

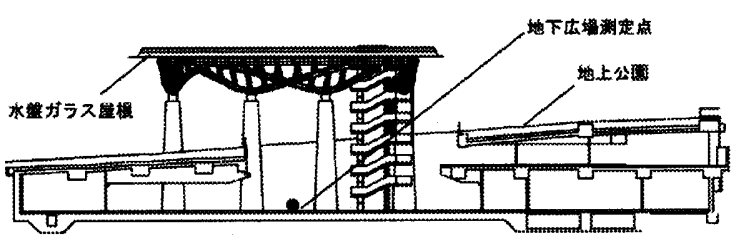

図 8 オアシス 21 の断面構成と测定点

\section{2 水盤ガラス屋根を有する空間の分光放射環境}

(1) オアシス 21 の概要

図 8 にオアシス 21 の断面図を示す. 地上の緑化公園にくり ぬかれた棈円形の地下広場と, 上部を覆う水盤ガラス屋根で構 成された半屋外空間である，地下広場から水盤ガラス屋根まで は約 $20 \mathrm{~m}$ の高さがあり，屋根中央部分に深さ約 $9 \mathrm{~cm}$ の水がた たえられ，屋根周辺部は歩廊となっている。

（2）水盤ガラス屋根の分光透過・吸収特性

図 9(a) は, 透明ガラスおよび水の分光屈折率および吸収係数 を文献 7)11) から引用したものである．屈折率は両者とも波長分 散は少ないが，吸収特性に影響を与える吸収係数については水 において波長分散が非常に大きいことがわかる.

図 9(b) は，この分光屈折率・吸収係数を用いて水 $(90 \mathrm{~mm})$ とガラス $(24 \mathrm{~mm})$ の構成体の入射角 $0^{\circ}$ での多重反射計算から 分光透過率・反射率を算出し，水盤部分・ガラス部分の正味の 吸収率を波長別に求めたものである．現場での透過・反射率実 測値と計算值を比較すると，実際のガラスは透明ガラスではな く膜面を挟んだ合せガラスであったものの, 透過率の可視光域 から近赤外にいたる変化がよく一致していることがわかる．分 光吸収率を見ると，水盤は透明ガラスを上回る可視光域の透過 


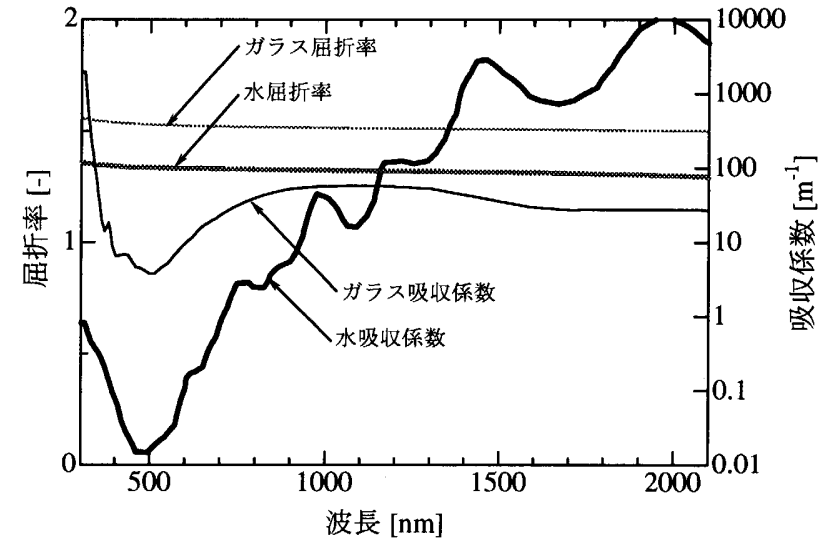

(a) 分光屈折率 ・ 吸収係数 7)11)

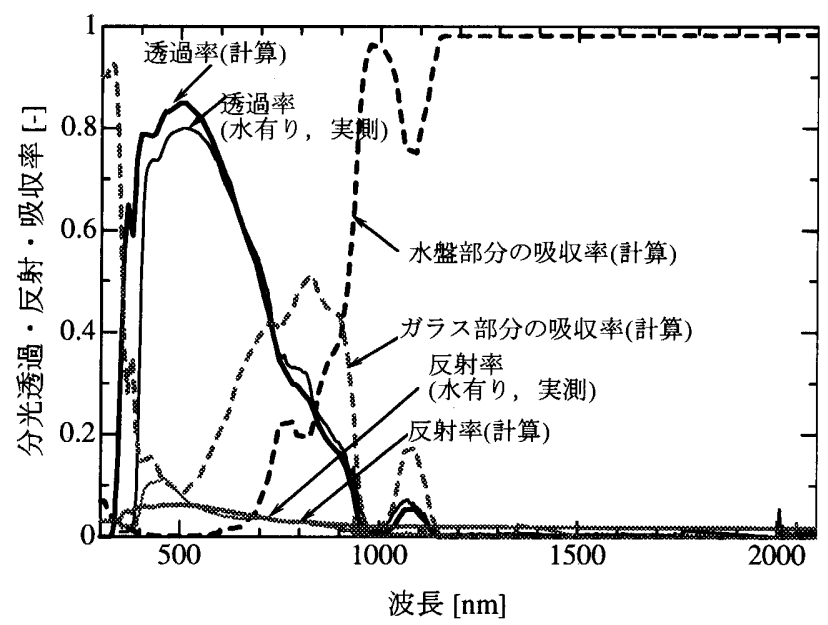

(b) 分光透過 - 吸収率

図 9 水盤の分光特性

性と近赤外域の日射を大幅に吸収する波長選択性が明確に表れ ている.

(3) 水盤の透過日射低減効果

水盤が有する波長選択性による日射遮蔽効果を検討するため, 図 10 に夏季実測期間中に水盤の水を抜いた場合 (a) と, 比較的 同じ気象条件で同時刻の水がある場合 (b)における, 基準化放 射輝度の波長帯比率 $\kappa_{\mathrm{NIR}} / \kappa_{\mathrm{UV}}+\mathrm{V}$ の空間分布を示した. 水が ない場合はガラス屋根部分が 0.4-0.8 程度で分布しているのに 対して, 水がある場合は 0.2-0.4 程度と約半分になっていること がわかる.

図 11 は, 図 10 上の $\kappa_{\mathrm{UV}+\mathrm{V}}$ および $\kappa_{\mathrm{NIR}}$ をプロットしたも のであるが, ガラス水盤屋根での水による波長選択性効果によ る差が明確に表れている.

\section{5 まとめ}

波長域 350-2500nm の分光放射計を用いた都市屋外・半屋外 の分光放射輝度および分光放射量計測に基づく分光放射環境の 分析によって，以下の知見を得た。

都市キャノピー構成面の日射反射率は, 近赤外域が紫外可視 光域よりも高い傾向である.

キャノピー壁面経由の分光放射量を測定時の全天日射の分光

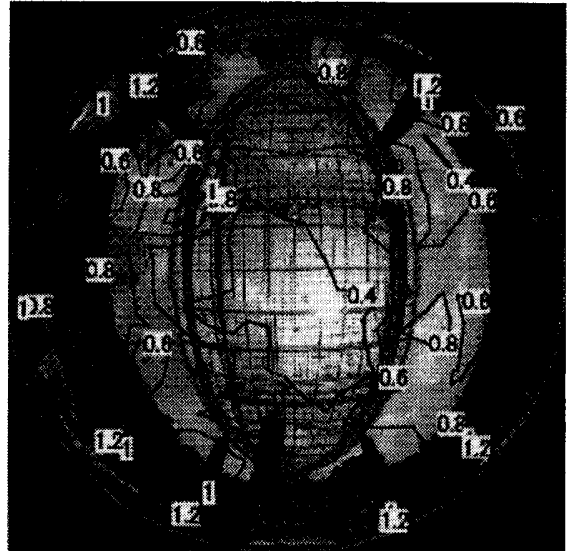

(a) 水なし $(2003.8 / 2$ 12:00)

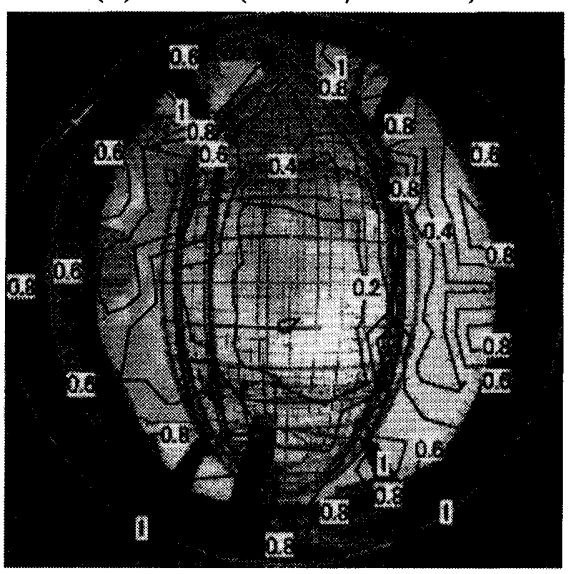

(b) 水あり (2003.8/4 12:14)

図 10 水盤ガラス屋根下における基準化放射輝度の波長帯比率 $\kappa_{\mathrm{NIR}} / \kappa_{\mathrm{UV}+\mathrm{V}}$ の空間分布

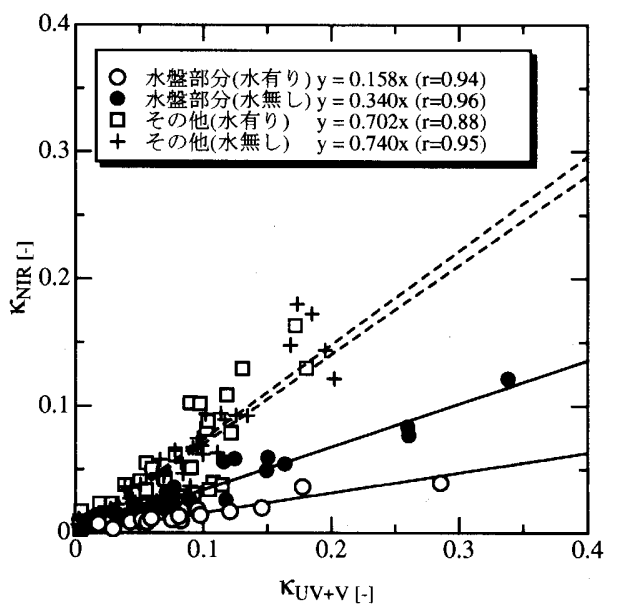

図 11 水盤ガラス屋根下における地物別の基準化放射輝度の波長帯 特性

分布で基準化して評価した結果, 熱線反射ガラス壁面からキャ ノピー下部に鏡面反射する日射がある場合は紫外可視光域の日 射が顕著に多く到達しているのに対して，その他では概ね近赤 外域の日射が多い.

壁面相互反射も含んだキャノピー空間での分光放射輝度分布 を, 測定時の全天日射の分光分布で基準化して評価した結果, 暴 天と晴天時では指向反射の影響で若干傾向が異なるが，樹木・低 
放射ガラス・壁体などからの放射輝度は近赤外域が紫外可視光 域より大きく，熱線反射カラスや透明ガラスは紫外可視光域の 方が大きい。

キャノピー下部と同様に, アトリウム下部における分光放射

量を全天日射基準で評価した結果，ガラスが有する紫外可視光 域の高い透過特性が反映され, 紫外可視光域の日射が多い.

水盤ガラス屋根下の空間においては, 水が有する近赤外域の 波長選択吸収によって，通常のガラス空間よりも近赤外域の日 射が大幅に少ない，

既報 ${ }^{6)}$ で検討した建材日射物性値の分光特性と同様に，紫外 可視光域および近赤外域の 2 波長帯によって, 都市屋外・半屋 外における分光放射環境の波長特性を反映できる.

\section{【参考文献】}

1) 鄭椙元, 堀越哲美, 梅村茂樹, 宮本征一, 水谷章夫 : 都市の街路 及び開放空間における熱放射環境が人体に及ぼす影響, 日本建築 学会計画系論文集 第 493 号, pp.77-84, 1997.4

2）足永靖信 : 屋外空間における短波および長波の放射強度の分布 に関する実測，日本建築学会計画系論文集 第 500 号, pp.71-77, 1997.10
3）浅野耕一，梅干野昆，山田貴代，松永徹志：建築外部空間におけ る熱環境解析のための 3 次元熱画像の作成方法に関する研究, 日 本建築学会計画系論文集 第 508 号, pp.35-41, 1998.6

4）郡公子, 石野久彌, 古川貴宏 : アトリウム各面からの輻射熱の影 響評価に関する実測研究, 日本建築学会計画系論文集 第 535 号, pp.9-14, 2000.9

5）成田千恵，田辺新一，尾関義一，小西正哲：日射の波長特性が温 熱感に与える影響に関する研究, 日本建築学会計画系論文集 第 545 号, pp.29-35, 2001.7

6)一ノ瀬雅之, 石野久凃, 永田明寛 : 建材の日射透過および反射 性能における分光感度特性，日本建築学会環境系論文集 第 583 号, pp.15-21, 2004.9

7) 近藤純正 : 水環境の気象学, 朝倉書店, 1994

8) Richard E. Bird, A Simple, Solar Spectral Model for DirectNormal and Diffuse Horizontal Irradiance, Solar Energy, Vol.32 No.4, pp.461-471, 1984

9）萩島理, 谷本潤, 片山忠久, 執行亮吉 : 都市キャノピー構成面の 日射反射率特性に関する調查研究，日本建築学会計画系論文集 第 560 号, pp.45-50, 2002.10

10）吉田篤正, 出井誠一，富永和秀，国友孟：太陽光に対する屋外 環境表面の分光反射特性に関する研究，日本機会学会論文集 (B 編) 54 巻 497 号, pp.172-177, 1988.1

11) M.Rubin, Optical Properties of Soda Lime Silica Glasses, Solar Energy Materials 12, pp.275-288, 1985 